\title{
Changes in Cytosolic Androgen Receptor after Administration of Testosterone of Androgen-Dependent Mouse Mammary Tumor (Shionogi Carcinoma) and Its Sublines of Altered Androgen Dependency
}

\author{
Hideki fUSE, Susumu AKIMOTo, Ryoko SATo, Taisei MiYAUCHI, \\ MASAMI WAKISAKA, TOICHIRo HOSOYA* AND JUN SHIMAZAKI \\ Department of Urology, School of Medicine, Chiba University, \\ Chiba, 280, and *Laboratory of Biophysical Chemistry, \\ Faculty of Pharmaceutical Sciences, Chiba University, Chiba, 260.
}

\begin{abstract}
The effect of testosterone treatment on the cytosolic androgen receptor in an androgen-dependent tumor (Shionogi Carcinoma 115, SC 115) and its sublines of altered hormone-dependency (CS 1, less androgen-dependent, and CS 2, androgenindependent) was examined. In all tumors examined a single, high-affinity binding to ${ }^{3} \mathrm{H}-\mathrm{R} 1881$ was detected in cytosols. The size of the maximum binding sites was in the order SC 115, CS 1 and CS 2 . Inhibition experiments revealed that the binding to ${ }^{3} \mathrm{H}-\mathrm{R} 1881$ in cytosols of these tumors was attributable to the androgen receptor. The amount of the androgen receptor in cytosols was decreased at $1 \mathrm{hr}$ after testosterone injection, then replenished gradually towards the pretreatment level. Depletion of the androgen receptor was dependent on the dose of testosterone administered. Multiple injections of testosterone depressed the replenishment of the receptor. Treatment with actinomycin $\mathrm{D}$ or cycloheximide did nct alter the dynamics of the androgen receptor. Therefore, it was concluded that the depletion and replenishment of the andrcigen receptor in cytosols of the tumors were caused by receptor recycling. Because a similar pattern of depletion and replenishment of the androgen receptor was also observed in the less androgen-dependent and -independent tumors, the growth of tumors was felt to be unrelated to the receptor dynamics.
\end{abstract}

It has been well discussed that receptors for androgen, estrogen or progestin in cytosols of target tissues enter nuclei after forming steroid-receptor complexes (O'Malley et al., 1976). A part of the receptors which have been transferred into nuclei return to cytoplasm, so that depletion and replenishment of receptor in cytosols of the target tissue seem to be the first step in the steroid hormone action (Luu Thi et al., 1975, Mešter and Baulieu, 1975, Isomaa et al., 1979). Recently it was observed that

Received January 17, 1983 some of the receptors which enter nuclei remained as a nuclear-bound form for a rather long time, but the physiological meaning of the long retention of the receptors in nuclei is obscure (Kassis and Gorski, 1981).

A transplantable mouse mammary carcinoma (Shionogi Carcinoma 115: SC 115) was established by Minesita and Yamaguchi (1964), and this tumor is known to be androgen-dependent, since the SC 115 grows only in male mice, and not in female or castrated male mice. The androgen receptor which binds with testosterone and 
dihydrotestosterone (Yamaguchi et al., 1978) has been observed in this tumor. Incorporation of testosterone in nuclei of the tumor was also found, so that the effect of androgen on the growth of SC 115 seems to be mediated by the androgen receptors (Matsumoto et al., 1972, Yamaguchi et al., 1974). The present study was undertaken to examine changes in the cytoplasmic androgen receptors from the SC 115 after the administration of testosterone in an attempt to clarify the role of androgen receptors in the regulation of growth of androgen-dependent tumor by comparing them with those from less androgen-dependent and -independent sublines of the SC 115.

\section{Materials and Methods}

\begin{abstract}
Animals
Adult male mice of $\mathrm{DD} / \mathrm{S}$ strain weighing approximately $25 \mathrm{~g}$ at the time of tumor transplantation were used throughout the experiments. This strain was originally supplied by the Shionogi Research Laboratory and has been maintained by inbreeding in our laboratory. Castration was performed via the scrotal route when tumors grew to approximately $2 \mathrm{~cm}$ in diameter. To estimate the androgen binding in tumors of testosterone-uninjected mice (uninjected control), tumors were removed $48 \mathrm{hr}$ after castration. Except where otherwise indicated, a single injection of testosterone was given subcutaneously with a dose of $100 \mu \mathrm{g} /$ animal dissolved in $0.2 \mathrm{ml}$ of $30 \%$ ethanol-saline at $48 \mathrm{hr}$ after castration, and the mice were sacrificed at appropriate intervals. When multiple testosterone injections were given, each $100 \mu \mathrm{g}$ of testosterone was injected at the indicated time. Actinomycin D $(30 \mu \mathrm{g} / 100 \mathrm{~g}$ body weight) or cycloheximide $(2.5 \mathrm{mg} / 100 \mathrm{~g}$ body weight) was injected intraperitoneally at the same time of testosterone injection.
\end{abstract}

\section{Tumors}

The SC 115 was supplied by the Shionogi Research Laboratory and has been maintained in our laboratory. Chiba Subline 1 (CS 1) and 2 (CS 2) were derived from the original SC 115 during transplantation in 1976 (CS 1) and 1981 (CS 2). The CS 1 grows in male mice faster than in female mice, indicating that the androgen dependency of CS 1 is less prominent (Wakisaka et al., 1980). The CS 2 grows equally in both male and female mice, therefore, is referred to as androgen independent. The histological features of these three tumors are similar to each other and they are undifferentiated medullary adenocarcinomas. The SC 115 and CS 1 have been maintained in male host mice, and the CS 2 in female recipients. Tumors used in the present experiments were 295th-302th generations in the SC 115, 60th-70th in the CS 1 and 34th-40th in the CS 2 .

For transplantation of tumors pieces of tumor tissues, approximately $5 \mathrm{mg}$ in wet weight (approximately $10^{7}$ cells) was implanted subcutaneously with a trocar in the dorsomedian region of the necks of recipient mice. Tumors became palpable on approximately the 8 th day after transplantation, then exponential growth followed.

\section{Tissue preparation}

Animals were sacrificed by cervical dislocation, removed tumors were placed on ice, and necrotic tissues were separated. All procedures were performed at $0-4^{\circ} \mathrm{C}$. The tumor tissues were minced with scissors, homogenized in 5 volumes of $0.01 \mathrm{M}$ Tris- $\mathrm{HCl}$ buffer ( $\mathrm{pH}$ 7.4) containing $1 \mathrm{~mm}$ EDTA, $1 \mathrm{mM} \beta$-mercaptoethanol and $10 \%(\mathrm{w} / \mathrm{v})$ glycerol (TEMG buffer) using a glass homogenizer and filtered through nylon cloth. Cytosols were obtained after centrifuging the homogenate at $105,000 \times g$ for $60 \mathrm{~min}$. Cytosols thus obtained were used for saturation analyses. When cytosols from mice injected with testosterone were assayed, one fourth volume of $0.25 \%$ dextran-coated $2.5 \%$ charcoal in TEMG buffer was poured into cytosols, mixed, centrifuged briefly, and the resulting supernatants were used.

\section{Saturation analysis of the binding}

Samples to be analyzed were incubated in $0.5 \mathrm{ml}$ of TEMG buffer containing various concentrations (0.25-5 nM) of ${ }^{3} \mathrm{H}-\mathrm{R} 1881$ ([17 $\alpha$-methyl- $\left.{ }^{3} \mathrm{H}\right] 17 \beta$-hydroxy-17 $\alpha$-methyl-estra-4, 9, 11-trien-3-one, specific activity $87 \mathrm{Ci} / \mathrm{mmol}$, New England Nuclear, Boston, USA) at $4^{\circ} \mathrm{C}$ for $16 \mathrm{hr}$. The ${ }^{3} \mathrm{H}$-ligand was dissolved in $0.01 \mathrm{ml}$ of ethanol and added to the incubation tube. After incubation, $0.05 \%$ dextran-coated $0.5 \%$ charcoal was added, centrifuged, and radioactivity in an aliquot of the supernatant was counted with $15 \mathrm{ml}$ of toluene containing $0.4 \%$ PPO and $0.01 \%$ POPOP in a liquid spectrophotometer (LKB 1215 Rackbeta, Wallac OY, Finland). In parallel incubations, 1000fold molar excess of unlabeled R 1881 was added to the incubation tube and nonspecific binding which was not displaced under these conditions was subtracted in all instances from the total binding to calculate specific binding. Binding capacity and affinity were analyzed by the method of Scatchard (1949).

When the effect of additive steroids on the R 1881 binding was examined, the additives were dissolved in another $0.01 \mathrm{ml}$ of ethanol and added to the incubation mixture directly. 


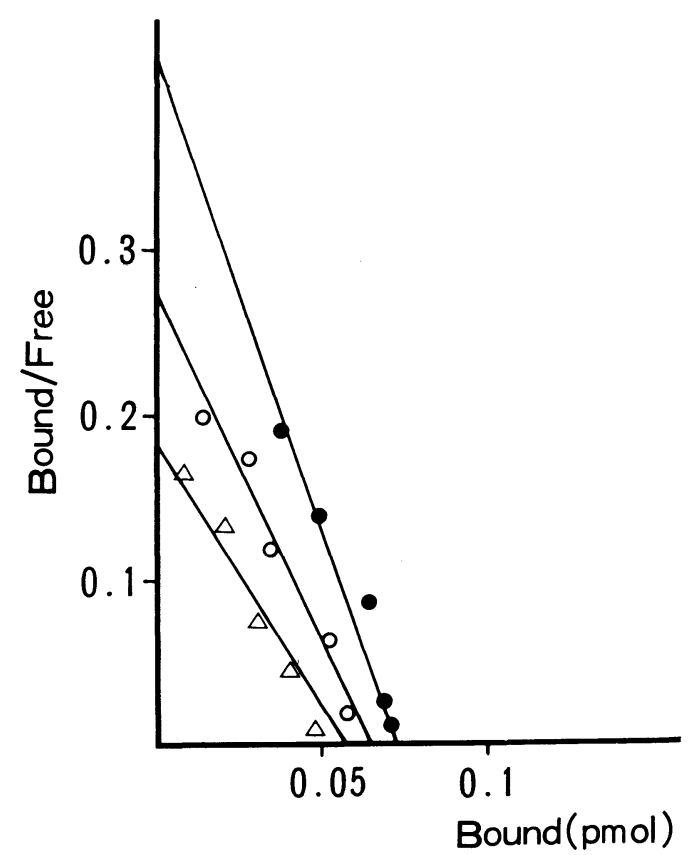

Fig. 1. Scatchard plot of binding to ${ }^{3} \mathrm{H}-\mathrm{R} 1881$ of cytosols from SC 115, CS 1 and CS 2. Cytosols of SC 115 (closed circle), CS 1 (open circle) and CS 2 (open triangle) were incubated with various concentrations of ${ }^{3} \mathrm{H}-\mathrm{R} 1881$ at $4^{\circ} \mathrm{C}$ for $16 \mathrm{hr}$. Dissociation constant $(\mathrm{Kd})$ and maximum binding sites from the Fig. are $0.34,0.40$ and $0.54 \times 10^{-9} \mathrm{M}$ and 17,11 and $10 \mathrm{fmol} / \mathrm{mg}$ protein in SC 115, CS 1 and CS 2, respectively.

\section{Protein determination}

Protein was measured by the biuret method (Gornall et al., 1949) with bovine serum albumin as the calibration standard.

\section{Results}

Binding to ${ }^{3} \mathrm{H}-\mathrm{R} 1881$ of cytosols from SC 115, CS 1 and CS 2

A single high-affinity binding to ${ }^{3} \mathrm{H}-\mathrm{R}$ 1881 was observed in cytosols from the SC 115, CS 1 and CS 2 (Fig. 1). The dissociation constants $(\mathrm{Kd})$ were almost identical in all three tumors (Table 1). Maximum binding sites were larger in the order SC 115, CS 1, and CS 2.

Table 1. Binding of cytosols from SC 115,

\begin{tabular}{lccc} 
& \multicolumn{2}{c}{ CS 1 and CS 2 to } & \\
& No. of & Kd & Maximum binding \\
assays & & $\begin{array}{c}\text { M } \\
\times 10^{-9} \mathrm{M}\end{array}$ & $\begin{array}{c}\text { sites } \\
\text { fmol/mg protein }\end{array}$ \\
\hline \hline SC 115 & 23 & $0.36 \pm 0.06$ & $17 \pm 2$ \\
CS 1 & 10 & $0.43 \pm 0.11$ & $11 \pm 2$ \\
CS 2 & 9 & $0.49 \pm 0.15$ & $9 \pm 1$ *b \\
\hline
\end{tabular}

Data are shown as Mean \pm S.E.

a: Three or four mice were used in one determination.

$\mathrm{b}$ : Statistically significant differences from that of the SC $115(\mathrm{p}<0.05)$.

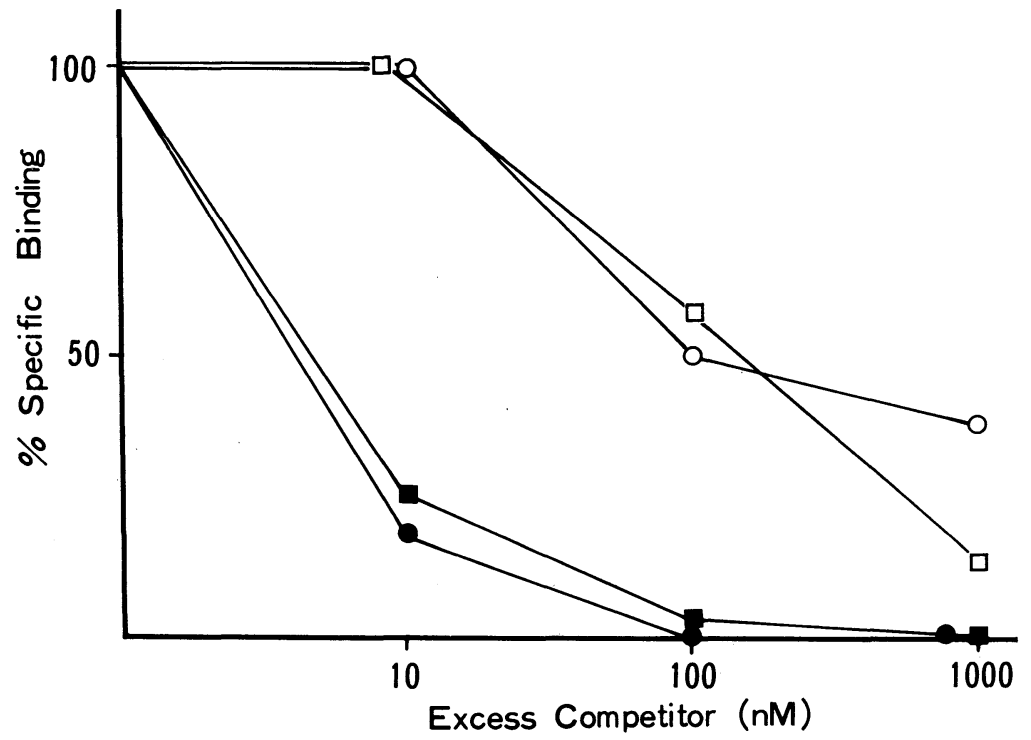

Fig. 2. Inhibition of ${ }^{3} \mathrm{H}-\mathrm{R}$ 1881 binding in cytosol from SC 115. Cytosol $(5.6 \mathrm{mg}$ as protein/tube) was incubated with $1 \mathrm{nM}$ of ${ }^{3} \mathrm{H}-\mathrm{R} 1881$ in the presence of various concentrations $(10-1000 \mathrm{nM})$ of radioinert steroids (closed circle; R 1881, closed square ; dihydrotestosterone, open circle; estradiol-17 $\beta$, open square; R 5020) at $4^{\circ} \mathrm{C}$ for $16 \mathrm{hr}$. The binding is expressed as a percentage of the binding incubated in the absence of competitors (11 fmol/mg protein). 
The cytosol from SC 115 was incubated with ${ }^{3} \mathrm{H}-\mathrm{R} 1881$ in the presence or absence of an excess amount of either dihydrotestosterone, $\mathrm{R} 1881, \mathrm{R} 5020$ or estradiol-17 $\beta$ (Fig. 2). Dihydrotestosterone showed a potent inhibition which was similar to that by $\mathrm{R} 1881$, indicating that binding of ${ }^{3} \mathrm{H}-\mathrm{R}$ 1881 was of the androgen receptor. Inhibition by estrogen and progestin was rather weak.

Time course changes in the binding of ${ }^{3} \mathrm{H}-\mathrm{R}$ 1881 in cytosols from SC 115, CS 1 and CS 2 after testosterone administration

To determine the rate of exchange of androgen-bound receptor with ${ }^{3} \mathrm{H}-\mathrm{R}$ 1881, the cytosol was preincubated with $10 \mathrm{~nm}$ of radioinert testosterone or dihydrotestosterone at $4{ }^{\circ} \mathrm{C}$ for $6 \mathrm{hr}$. After treatment with dextran-coated charcoal, the supernatant was again incubated with ${ }^{3} \mathrm{H}-\mathrm{R}$ 1881. Maximum binding sites were calculated and compared with that of the cytosol which was not preincubated. ${ }^{3} \mathrm{H}-\mathrm{R} 1881$ bindings were approximately $73 \%$ and $48 \%$ of those of cytosol without preincubation in the cytosols preincubated with testosterone and dihy- drotestosterone, respectively. Thus, appreciable amounts of the binding of cytosol to testosterone and dihydrotestosterone were exchangeable in the incubation conditions used in the present study.

Tumor-bearing castrated mice which received testosterone were sacrificed to observe time course changes in the binding of ${ }^{3} \mathrm{H}-\mathrm{R} 1881$ in cytosols (Fig. 3). One hour after testosterone administration, the binding of ${ }^{3} \mathrm{H}-\mathrm{R} 1881$ was significantly diminished when compared with that of the respective uninjected control, and rates of reduction were $70 \%, 68 \%$ and $60 \%$ in the SC 115, CS 1 and CS 2, respectively. Thereafter, the binding of ${ }^{3} \mathrm{H}-\mathrm{R} 1881$ was increased gradually, and six hours after testosterone injection the binding from the SC 115 and CS 2 reached two thirds of that of the uninjected controls, while at this time, the binding of ${ }^{3} \mathrm{H}-\mathrm{R} 1881$ in the CS 1 passed the uninjected control level.

Scatchard plots of the binding of ${ }^{3} \mathrm{H}-\mathrm{R}$ 1881 in cytosols of the SC 115 from the testosterone-injected and -uninjected mice are shown in Fig. 4. Although the maximum binding sites in cytosols from animals

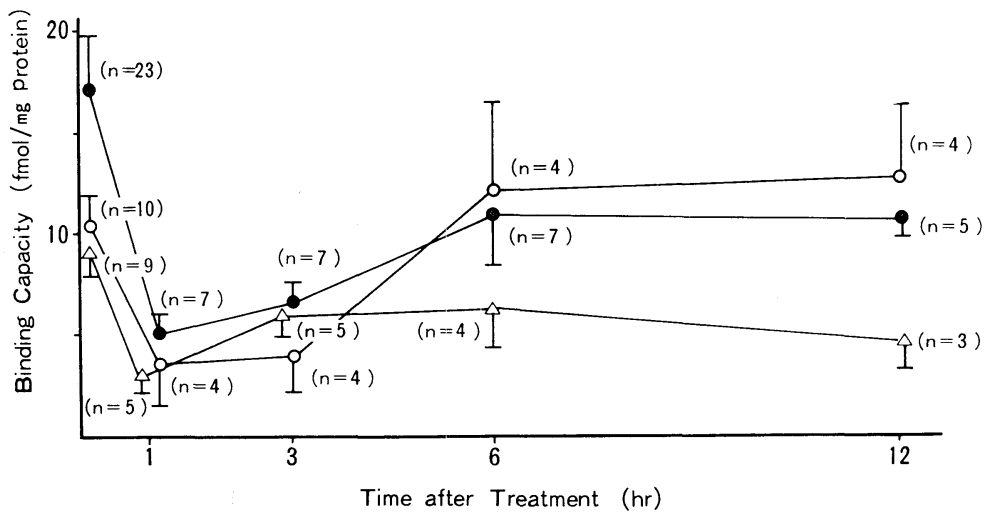

Fig. 3. Time course changes in ${ }^{3} \mathrm{H}-\mathrm{R} 1881$ binding of cytosols from SC 115, CS 1 and CS 2 after testosterone administration. Cytosols prepared from tumors of testosterone-uninjected mice (ordinate) or from tumors of castrated mice sacrificed at indicated time after testosterone injection were treated with dextran-coated charcoal, then incubated with ${ }^{3} \mathrm{H}-\mathrm{R} 1881$. SC 115 (closed circle), CS 1 (open circle), CS 2 (open triangle). Maximum binding sites are expressed as Mean \pm S.E. (shown as bar) in experiments performed independently using 3-4 mice for one point ( $\mathrm{n}$; number of experiments). Statistically significant differences from values of the respective uninjected control are : SC 115 and CS $1(\mathrm{p}<0.02)$, CS $2(\mathrm{p}<0.01)$ at one $\mathrm{hr}$ after testosterone injection, SC 115 and CS 1 $(\mathrm{p}<0.05)$ at $3 \mathrm{hr}$ after testosterone injection. 


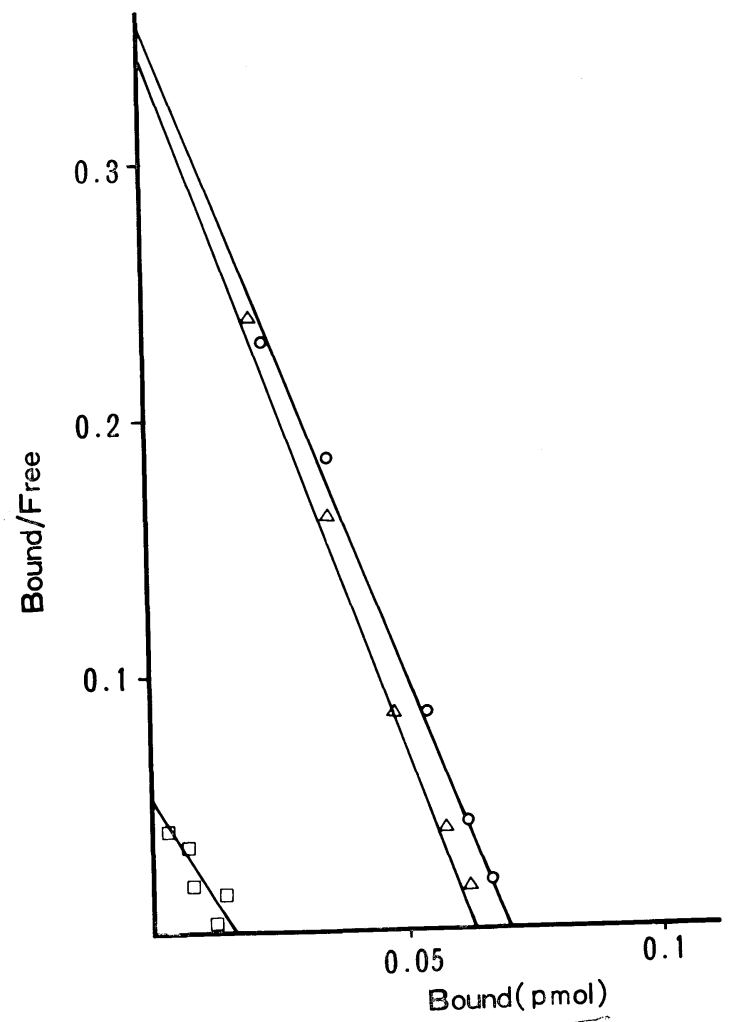

Fig. 4. Scatchard plot of binding to ${ }^{3} \mathrm{H}-\mathrm{R} 1881$ of cytosols from the uninjected control and the tumors removed from testosterone-injected mice. Open circle (the uninjected control), open square (one hr after testosterone injection), open triangle (six hr after testosterone injection). Kd's and maximum binding sites from the Fig. are 0.41 , 0.56 and $0.40 \times 10^{-9} \mathrm{M}$ and 17,5 and $14 \mathrm{fmol} / \mathrm{mg}$ protein in the uninjected control, one $\mathrm{hr}$ and $6 \mathrm{hr}$ treated tumors, respectively. which received testosterone injection one hour before sacrifice were small, $\mathrm{Kd}$ was almost identical to that of the uninjected control. The replenished receptor observed in tissues of animals which received the injection $6 \mathrm{hr}$ before also exhibited a similar Kd. Kd's of cytosols in the CS 1 and CS 2 were not influenced by the testosterone injection (data not shown).

The time course changes in the binding of ${ }^{3} \mathrm{H}-\mathrm{R} 1881$ was studied after the injection of various amounts of testosterone to SC 115-bearing castrated mice (Fig. 5). At one hour after testosterone injection, maximum binding sites in cytosols of the tumors were reduced to $43 \%, 50 \%, 79 \%$ and $86 \%$ of those of the uninjected control in $10,50,100$ and $200 \mu \mathrm{g}$ injected animals, respectively. Moreover, injection with larger amounts of testosterone sustained low binding for a longer time period. A similar dose-related depletion of the binding was also observed in the CS 1 and CS 2 (data not shown).

Multiple injections of testosterone to castrated animals bearing the SC 115, CS 1 and CS 2 caused a persistent depletion of the binding of ${ }^{3} \mathrm{H}-\mathrm{R} 1881$ throughout the experimental periods (Fig. 6).

Time course changes in the binding of ${ }^{3} \mathrm{H}-\mathrm{R} 1881$ were also determined in the SC 115 -bearing castrated mice which received

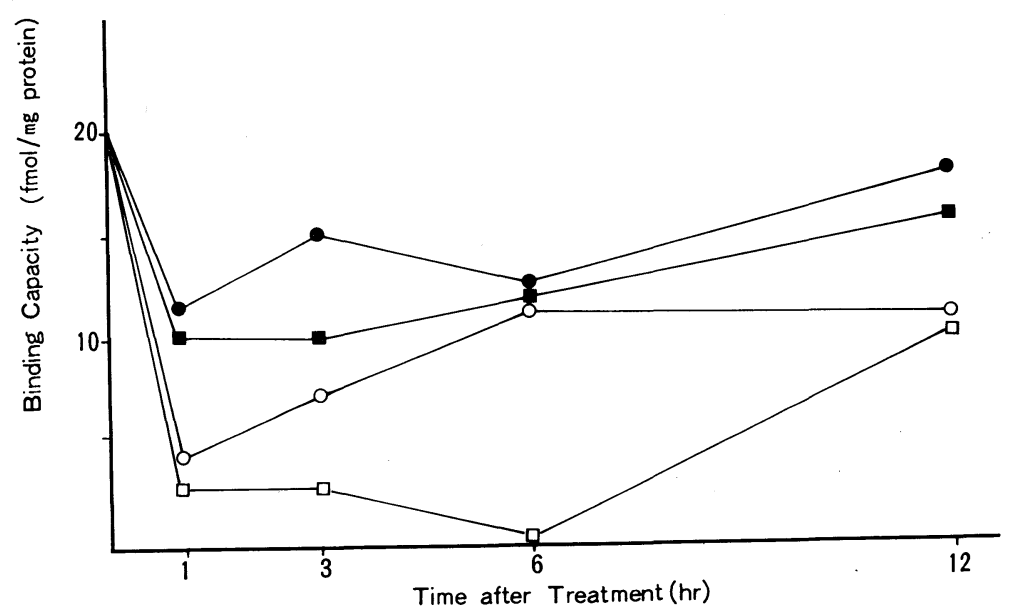

Fig. 5. Relationship between dose of testosterone administered and depletion of ${ }^{3} \mathrm{H}-\mathrm{R}$ 1881-binding in cytosols of SC 115. Various amounts of testosterone were injected and tumor-bearing mice were sacrificed at the indicated time. Results of one of the typical experiments are shown. Dose of testosterone/ mouse $(10 \mu \mathrm{g}$; closed circle, $50 \mu \mathrm{g}$; closed square, $100 \mu \mathrm{g}$; open circle, $200 \mu \mathrm{g}$; open square). 

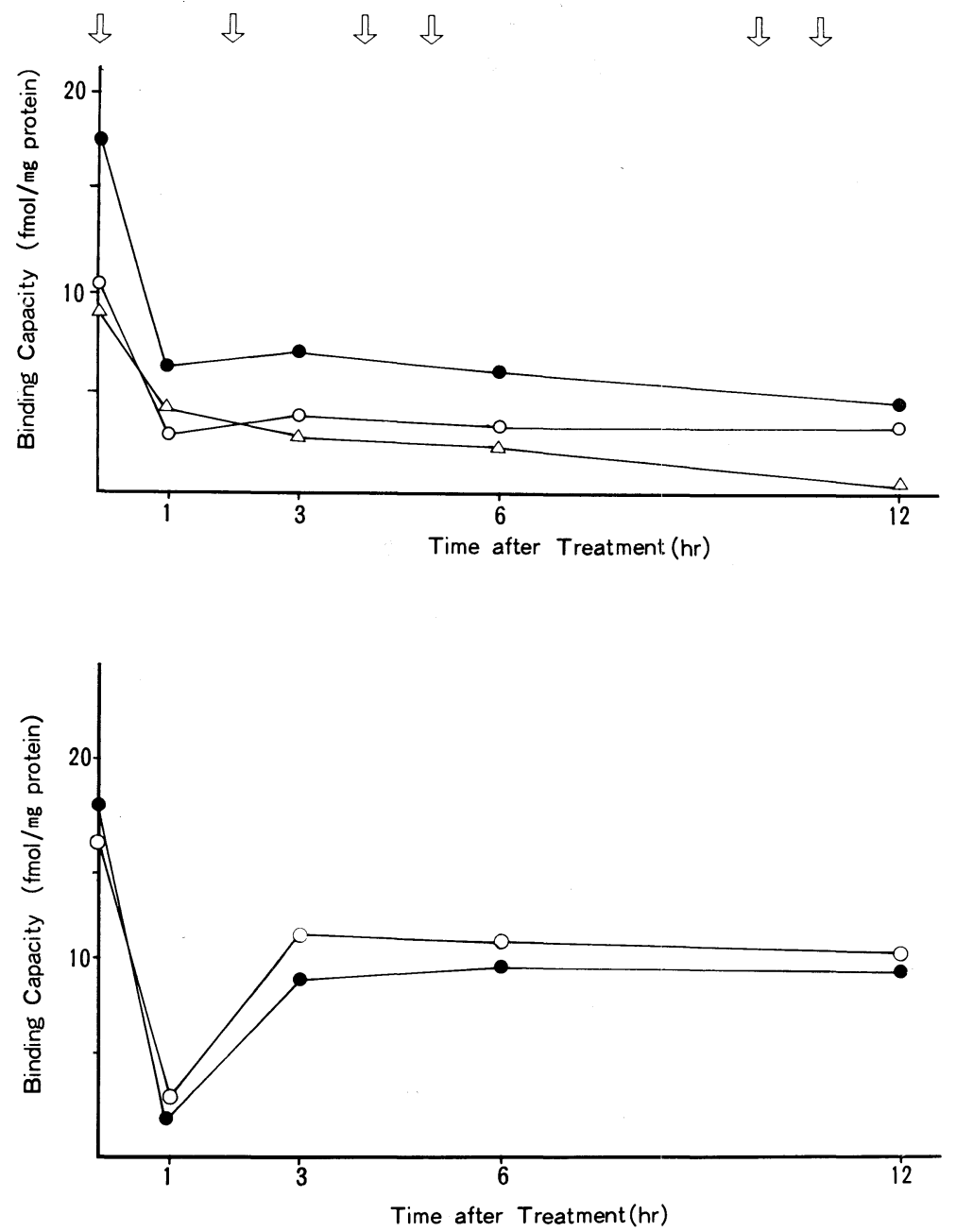

Fig. 6. Effect of multiple injections of testosterone on binding of ${ }^{3} \mathrm{H}-\mathrm{R} 1881$ to $\mathrm{cy}$ tosols of SC 115, CS 1 and CS 2. Tumor-bearing mice each received serial injections of $100 \mu \mathrm{g}$ of testosterone and binding of ${ }^{3} \mathrm{H}-\mathrm{R} 1881$ in cytosols was determined. $\mathrm{Re}-$ sults of a typical experiment are depicted. SC 115 (closed circle), :CS 1 (open circle), CS 2 (open triangle). Arrows indicate testosterone injection.

Fig. 7. Effect of actinomycin $D$ and cycloheximide on testosterone-induced depletion of ${ }^{3} \mathrm{H}-\mathrm{R} 1881$ binding in cytosol of SC 115. Actinomycin D (closed circle, $30 \mu \mathrm{g} /$ $100 \mathrm{~g}$ body weight) or cycloheximide (open circle, $2.5 \mathrm{mg}$ / $100 \mathrm{~g}$ body weight) were injected intraperitoneally at the same time of testosterone injection. Values on the ordinate are those obtained from the uninjected control. Results of one of typical experiments are shown. testosterone and actinomycin D concomitantly (Fig. 7). It was observed that depletion and replenishment of the binding to ${ }^{3} \mathrm{H}-\mathrm{R} 1881$ in the cytosol were not influenced by simultaneous injection of actinomycin D. Treatment of testosteroneinjected tumor-bearing mice with cycloheximide did not appear to have any effect on depletion and replenishment of the binding. These results suggest that depletion and replenishment of the binding after testosterone injection did not require new RNA and protein syntheses.

\section{Discussion}

The presence of the androgen receptor has been proved in the cytosol of SC 115 by many investigators using dihydrotestosterone or R 1881 as the ligand (Jung-Testas et al., 1976, King et al., 1976, Kitamura et al., 1978, Nohno, 1981). Binding to androgen of the androgen receptor and subsequent translocation of the hormone-receptor complex to nuclei are correlated to the growth response of the SC 115 (Sica et 
al., 1981). In the present study, the presence of the androgen receptor was shown in the SC 115 and also in its sublines of altered androgen dependency. Binding properties of the androgen receptor in the latter tumors were not different from those of the original SC 115 but the number of binding sites in the independent subline was significantly reduced. However, it has been reported by others that some androgen-independent sublines of the SC 115 contained androgen receptor, while in other androgenindependent sublines only trace amounts of binding component to androgen were detected (Bruchovsky et al., 1975, Bruchovsky and Rennie, 1978). In this context it has been generally accepted that the presence of the cytosol steroid receptor is not a direct indication of hormone responsiveness of the tumors (Nomura et al., 1977).

In the present experiments, ${ }^{3} \mathrm{H}-\mathrm{R} 1881$ was used as the ligand for determination of the androgen receptor in the cytosol of tumors. Although R 1881 binds to the androgen receptor as well as the progestinbinding component (Asselin et al., 1976, Zava et al., 1979), this ligand was widely used in the determination of the androgen receptor in prostates of rodents, since there were no detectable components binding to progestins in the prostates of rodents (Bonne and Raynaud, 1976, Pousette et al., 1979). From the results of the inhibition experiments in the present study, the binding of $\mathrm{R} 1881$ in the SC 115 also appeared to have the nature of androgen receptor. It was reported that the addition of molybdate stabilizes the binding to $\mathrm{R} 1881$ in cytosol of rodent prostate (Gaubert et al., 1980, Noma et al., 1980). In the present study, however, the binding to $\mathrm{R} 1881$ was observed without molybdate, since the preliminary experiments did not show any difference between the presence and absence of this ion in the incubation medium. Exchange of occupied binding sites with ${ }^{3} \mathrm{H}-\mathrm{R}$ 1881 was not complete, and higher rates of exchange were observed in receptors occupied with testosterone than with dihydrotestosterone. In the tissues of the SC 115, the activity of $5 \alpha$-reductase is low (Bruchovsky, 1972, Bruchovsky and Meakin, 1973), and the major androgen in the tissue after the injection of testosterone is unmetabolized testosterone (Matsumoto et al., 1972), so that androgen which occupies the receptor may be mainly testosterone under the experimental conditions used here. For these reasons, most of binding sites for androgens in the cytosol after testosterone injection could be measured by this method.

Depletion was equally observed in cytosols of three tumors of different androgen dependency (Fig. 3). Some autonomous sublines of the SC 115 showed nuclear androgen uptake which was similar to that observed in the androgen-dependent tumor (Bruchovsky and Rennie, 1978). However these authors noticed no specific binding in nuclear extracts of these autonomous sublines even though there was considerable nuclear androgen uptake. In the present experiments, an androgen-independent subline, CS 2, showed a depletion and replenishment of cytosolic receptor after testosterone administration, and this implied that the nuclear translocation of androgen-receptor complex took place in this tissue. Therefore, unresponsiveness to androgen in the CS 2 might be accounted for by reasons other than a defect in the nuclear translocation process. Previously, we observed that the effect of testosterone administration on an increase in RNA polymerase I was more meagre in the CS 1 than that in the SC 115 (Suzuki et al., 1983).

Lefebvre et al. (1982) reported that the rate of nuclear uptake of dihydrotestosterone after incubation of purified nuclei with dihydrotestosterone was high in the SC 115 and one autonomous subline, but it was low in the other. This seems to indicate that androgen binding of nuclei which is not mediated by the cytosolic androgen re- 
ceptor is not correlated to the hormone dependency of tumors.

The Kd of the replenished binding component in the liver after injection of glucocorticoid to rats was significantly greater than that of intact animals (Ichii, 1981). However, no significant difference in Kd's of androgen receptor before or after administration of testosterone was detected in the present study. Depletion of the $\mathrm{R}$ 1881binding was observed to be dependent on the dose of testosterone administered, and similar dose-related depletion of the androgen receptor in cytosols of the prostate of rats has already been reported (Ichii, 1980). Moreover, the injection of long-acting androgen kept the cytosolic androgen receptor of rat ventral prostate in a depleted state for a long period (Ichii, 1980). Multiple injections of testosterone also delayed the replenishment of the androgen receptor. Recycling of receptors seems to be the main cause of depletion and replenishment of the androgen receptor in the tumors, since actinomycin D or cycloheximide administered simultaneously with testosterone did not influence the replenishment of the receptor in the tumors. On the other hand, there have been reports indicating the requirement of new protein synthesis in the replenishment of receptors in cytosols (Jungblut et al., 1976, 1979, Korach and Ford, 1978).

\section{Acknowledgements}

The authors wish to thank Dr. K. Yamaguchi of the Shionogi Research Laboratory for donating the mouse mammary tumor (SC 115). This work was supported in part by Grants-in-Aid for Scientific Research and Cancer Research from the Ministry of Education, Science and Culture, and for Cancer Research from the Ministry of Health and Welfare, Japan.

\section{References}

Asselin, J., F. Labrie, Y. Gourdeau, C. Bonne and J. P. Raynaud (1976). Binding of $\left({ }^{3} \mathrm{H}\right)$ methyltrienolone ( $R$ 1881) in rat prostate and human benign prostatic hypertrophy (BPH). Steroids 28, 449-459.

Bonne, C. and J. P. Raynaud (1976). Assay of androgen binding sites by exchange with methyltrienolone (R 1881). Steroids 27, 497-507.

Bruchovsky, N. (1972). The metabolism of testosterone and dihydrotestosterone in an androgendependent tumour. A possible correlation between dihydrotestosterone and tumour growth in vivo. Biochem. J. 127, 561-575.

Bruchovsky, N. and J. W. Meakin (1973). The metabolism and binding of testosterone in androgendependent and autonomous transplantable mouse mammary tumors. Cancer Res. 33, 1689-1695.

Bruchovsky, N. and P. S. Rennie (1978). Classification of dependent and autonomous variants of Shionogi mammary carcinoma based on heterogenous patterns of androgen binding. Cell 13, 273-280.

Bruchovsky, N., D. J. A. Sutherland, J. W. Meakin and T. Minesita (1975). Androgen receptors: Relationship to growth response and to intracellular androgen transport in nine variant lines of the Shionogi mouse mammary carcinoma. Biochim. Biophys. Acta 381, 61-71.

Gaubert, C. M., R. R. Tremblay and J. Y. Dubé (1980). Effect of sodium molybdate on cytosolic androgen receptors. J. Steroid Biochem. 13, 931937.

Gornall, A. G., C. J. Bardawill and M. M. David (1949). Determination of serum proteins by means of the biuret reaction. J. Biol. Chem. 177, 751766.

Ichii, S. (1980). Changes in the cytoplasmic androgen receptor of rat ventral prostate after administration of androgens, antiandrogens and anabolic steroids. Endocrinol. Japon. 27, 483-493.

Ichii S. (1981). Depletion and replenishment of glucocorticoid receptor in cytosols of rat tissues after administration of various glucocorticoids. Endocrinol. Japon. 28, 293-304.

Isomaa, V., H. Isotalo, M. Orava and O. Jänne (1979). Regulation of cytosol and nuclear progesterone receptors in rabbit uterus by estrogen, antiestrogen and progesterone administration. Biochim. Biophys. Acta 585, 24-33.

Jungblut, P. W., J. Gaues, A. Hughes, E. Kallweit, W. Sierralta, P. Szendro and R. K. Wagner (1976). Activation of transcription-regulating proteins by steroids. J. Steroid Biochem. 7, 1109-1116.

Jungblut, P. W., A. Hughes, J. Gaues, E. Kallweit I. Maschler, F. Parl and W. Sierralta (1979). 
Mechanisms involved in the regulation of steroid receptor levels. J. Steroid Biochem. 11, 273-278.

Jung-Testas, I., W. Desmond and E. E. Baulieu (1976). Two sex steroid receptors in SC-115 mammary tumor cells. Exptl. Cell Res. 97, 219-232.

Kassis, J. A. and J. Gorski (1981). Estrogen receptor replenishment: Evidence for receptor recycling. J. Biol. Chem. 256, 7378-7382.

King R. J. B., G. J. Cambray and J. H. Robinson (1976). The role of receptors in the steroidal regulation of tumour cell proliferation. J. Steroid Biochem. 7, 869-873.

Kitamura, Y., S. Okamoto, N. Uchida, K. Yamaguchi and K. Matsumoto (1978). Effect of androgen depletion on growth and androgen dependency of Shionogi Carcinoma 115. Cancer Res. 38, 4711-4716.

Korach, K. S. and E. B. Ford (1978). Estrogen action in the mouse uterus: An additional nuclear event. Biochem. Biophys. Res. Comm. 83, 327-333.

Lefebvre, Y. A., J. J. Caskey and L. D. Kline (1982). Characterization of androgen uptake by purified nuclei from an androgen-dependent and two androgen-independent cell lines of the Shionogi mouse mammary carcinoma. J. Steroid Biochem. 17, 609-614.

Luu Thi, M. T., E. E. Baulieu and E. Milgrom (1975). Comparison of the characteristics and of the hormonal control of endometrial and myometrial progesterone receptors. J. Endocrinol. 66, 349-356.

Matsumoto, K., K. Kotoh, H. Kasai, T. Minesita and K. Yamaguchi (1972). Sub-cellular localization of radioactive steroids following administration of testosterone- ${ }^{3} \mathrm{H}$ in the androgen dependent mouse tumor, Shionogi Carcinoma 115. Steroids 20, 311-320.

Mešter, J. and E. E. Baulieu (1975). Dynamics of oestrogen-receptor distribution between the cytosol and nuclear fractions of immature rat uterus after oestradiol administration. Biochem. J. 146, 617623.

Minesita, T. and K. Yamaguchi (1964). An androgen-dependent tumor derived from a hormoneindependent spontaneous tumor of a female mouse. Steroids 4, 815-830.

Nohno, T. (1981). Binding kinetics and physical properties of androgen receptor in androgen-dependent Shionogi mammary carcinoma 115. $J$. Biochem. 89, 615-623.
Noma, K., K. Nakao, B. Sato, Y. Nishizawa, K. Matsumoto and Y. Yamamura (1980). Effect of molybdate on activation and stabilization of steroidal receptors. Endocrinology 107, 1205-1211.

Nomura, Y., S. Kobayashi, O. Takatani, H. Sugano, K. Matsumoto and W. L. McGuire (1977). Estrogen receptor and endocrine responsiveness in Japanese versus American breast cancer patients. Cancer Res. 37, 106-110.

O'Malley, B. W., R. J. Schwartz and W. T. Schrader (1976). A review of regulation of gene expression by steroid hormone receptors. J. Steroid Biochem. 7, 1151-1159.

Pousette, A., M. Snochowski, D. Bression, B. Högberg and J. A. Gustafsson (1979). Partial characterization of $\left({ }^{3} \mathrm{H}\right)$ methyltrienolone binding in rat prostate cytosol. Biochim. Biophys. Acta 582, 358367.

Scatchard, G. (1949). The attraction of protein for small molecules and ions. Ann. N. Y. Acad. Sci. 51, 660-672.

Sica, G., P. Longo, F. O. Ranelletti and S. Iacobelli (1981). Androgen receptor specificity and growth response in Shionogi carcinoma cells. J. Steroid Biochem. 14, 23-28.

Suzuki, N., M. Wakisaka, T. Miyauchi, J. Shimazaki and T. Hosoya (1983). Effect of sex hormones on RNA synthesis of androgen-dependent mouse mammary tumor (Shionogi Carcinoma). Endocrinol. Japon. 30, 15-21.

Wakisaka, M., H. Ohwada, K. Nozumi and J. Shimazaki (1980). Cell kinetic studies on androgendependent mouse mammary tumor and subline with altered dependency. Gann 71, 1-7.

Yamaguchi, K., H. Kasai, T. Minesita, K. Kotoh and K. Matsumoto (1974). 5 $5 \alpha$-Reduction and binding of testosterone in androgen-dependent and -independent mouse mammary tumors. Endocrinology 95, 1424-1430.

Yamaguchi, K., B. Sato, S. Okamoto, Y. Kitamura and K. Matsumoto (1978). In vivo and in vitro studies in androgen-dependent Shionogi Carcinoma 115. In : Hormones, Receptors, and Breast Cancer (W. L. McGuire ed.). Raven Press, New York. pp. 281-300.

Zava, D. T., B. Landrum, K. B. Horwitz and W. L. McGuire (1979). Androgen receptor assay with $\left({ }^{3} \mathrm{H}\right)$ methyltrienolone ( $\left.\mathrm{R} 1881\right)$ in the presence of progesterone receptors. Endocrinology 104, 1007 1012. 